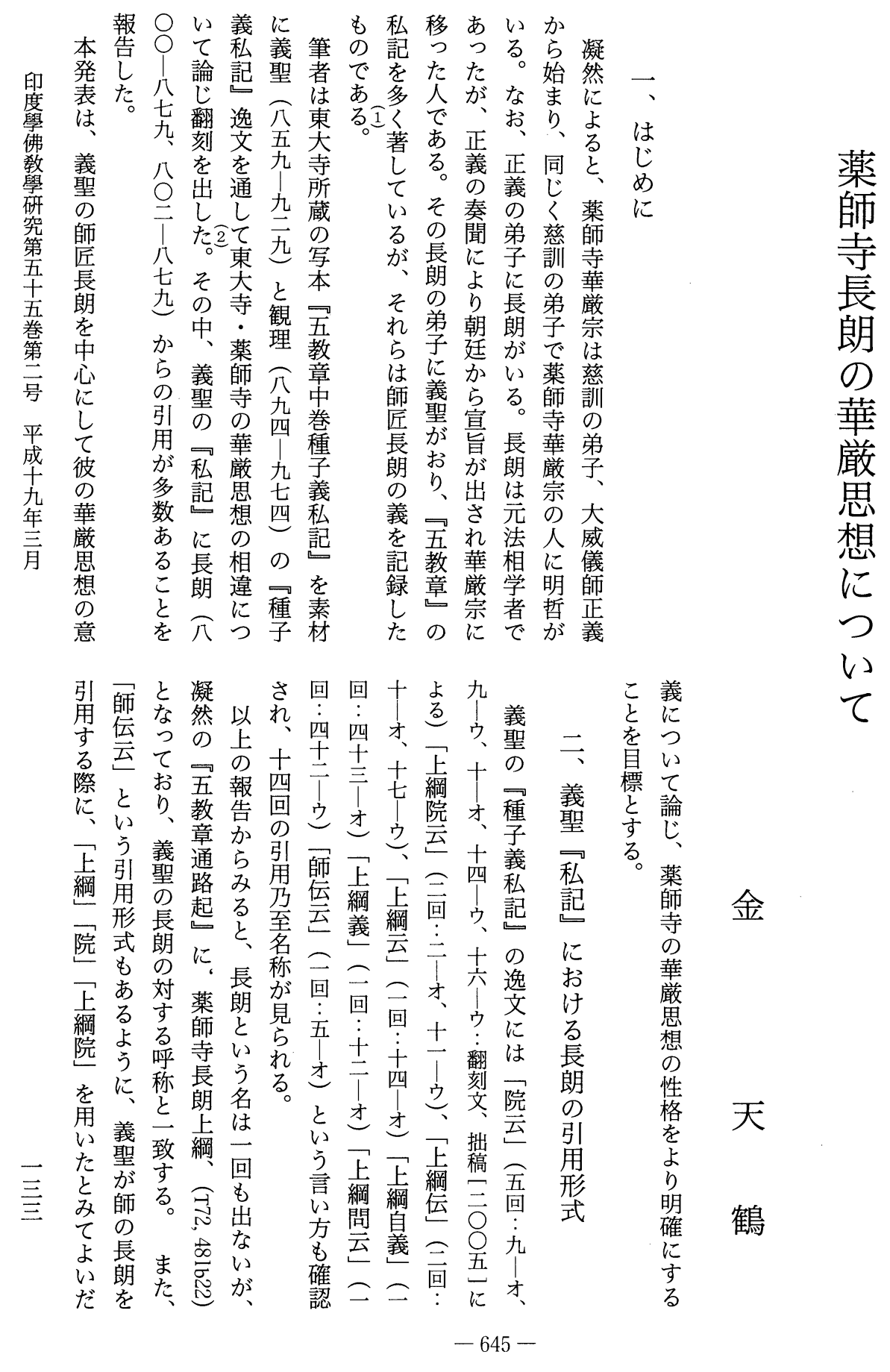




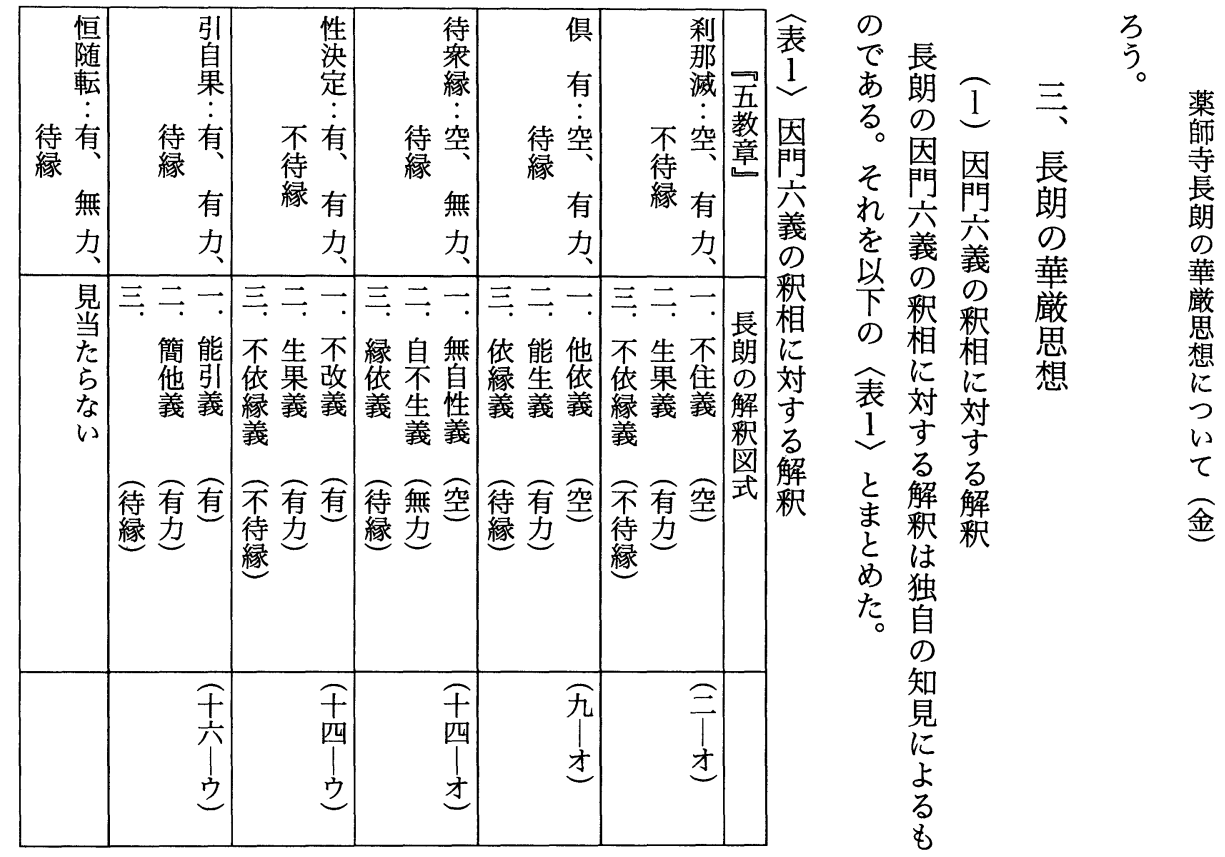

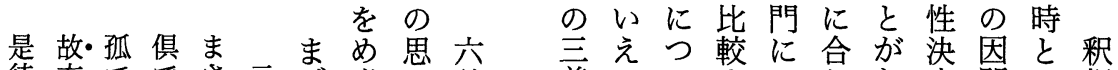

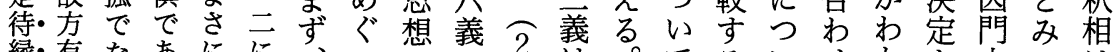

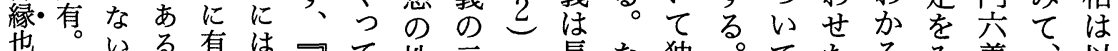

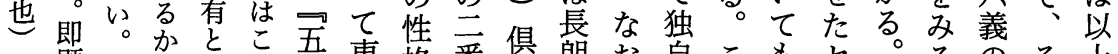

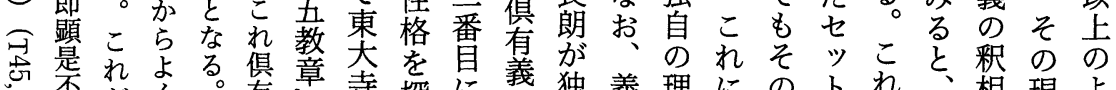
心否がくる具章寺探に義独義理にのトれ、相現よ 忍有待有即のに年る説の自聖解よ意のは三に在う 是縁を占義は薬上奛待的はをっ味図義当をで

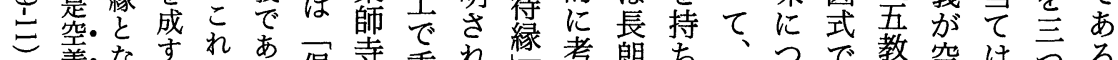

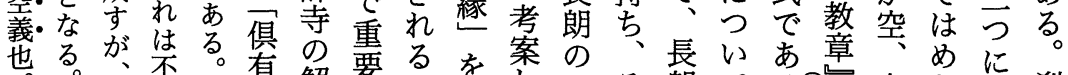

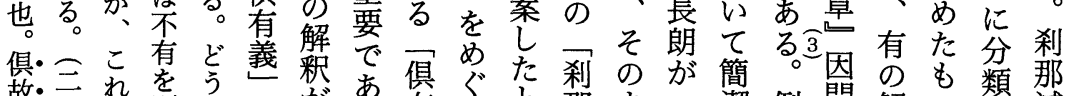

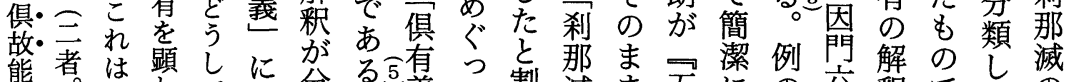

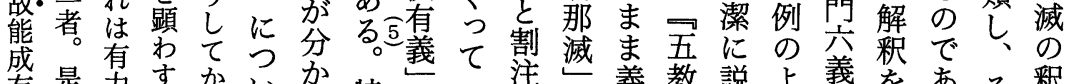

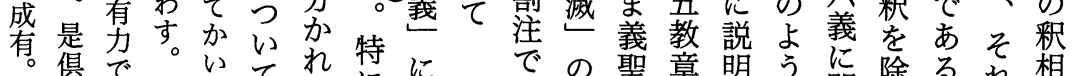

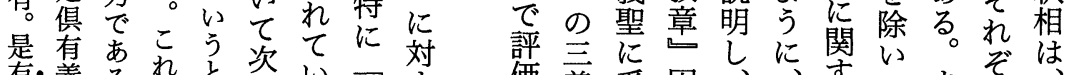

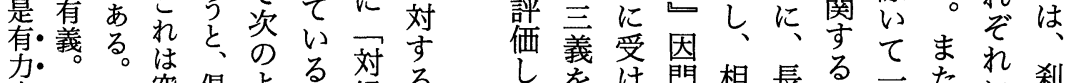

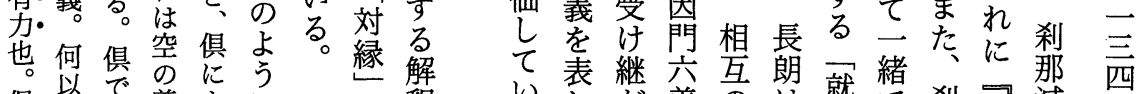

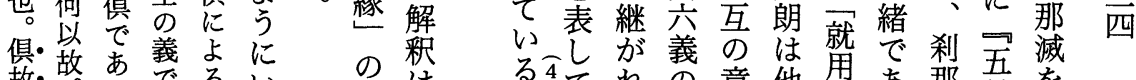

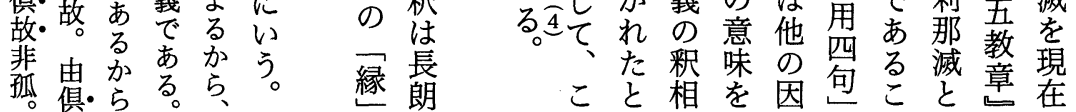


時の意々是もい対ち待長かのそでれい縁必縁因義 縁味い故まるもて緑朗し俱にるいるて待要組有待上

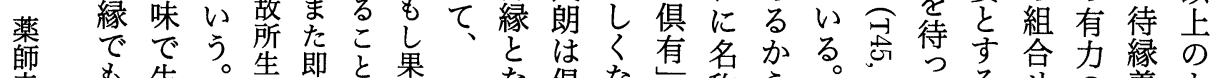

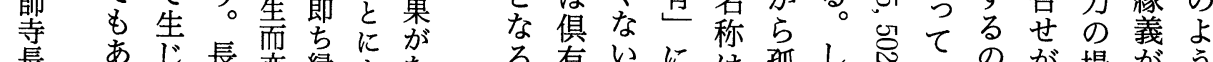
長あじ長亦縁ななる有いには孤し心てのが場がう

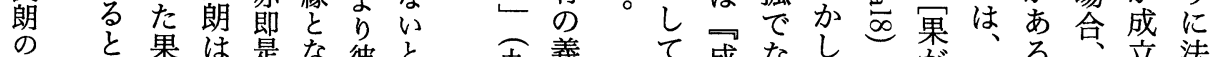

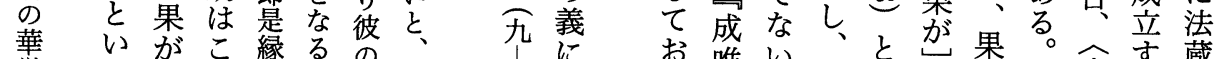

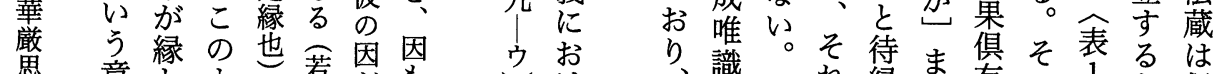

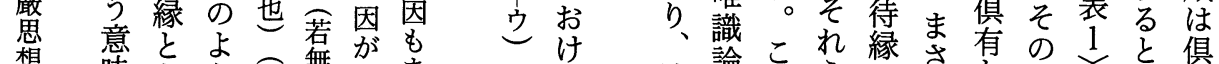

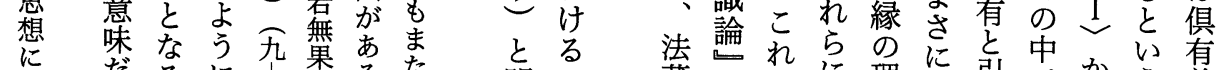
にたるにり奢るた

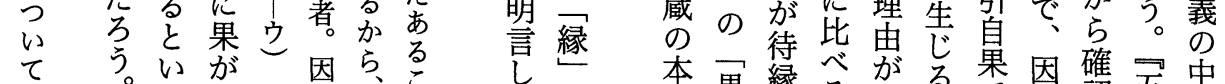

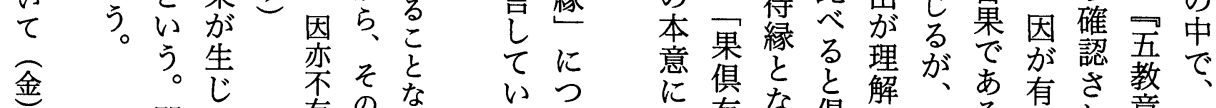

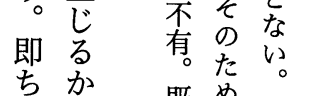
wo a.

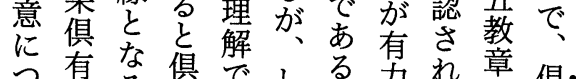
生 5 既 め

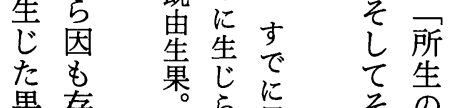

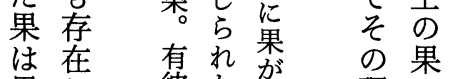

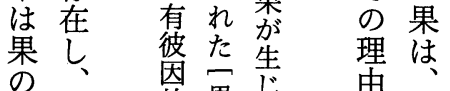

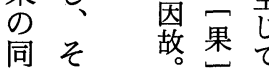

甹即

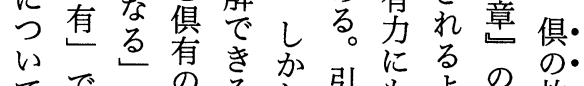

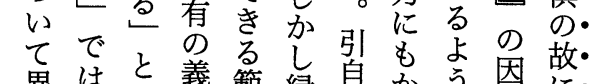

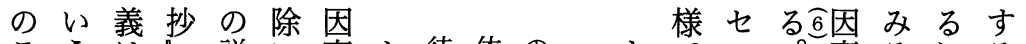

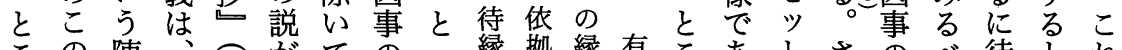

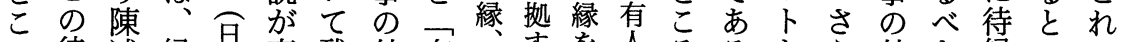

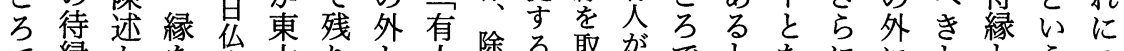

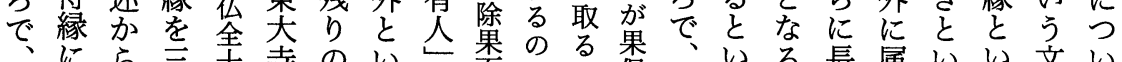

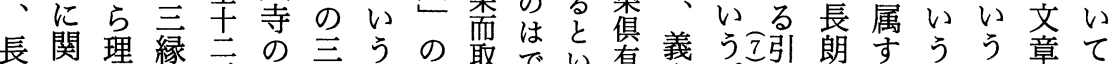

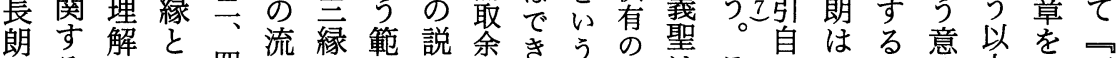

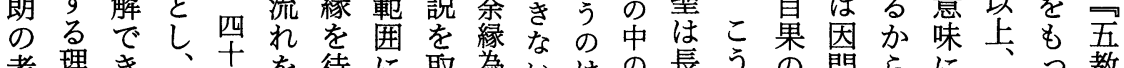

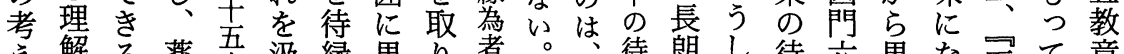

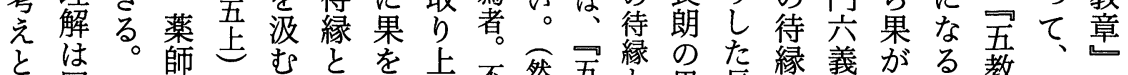

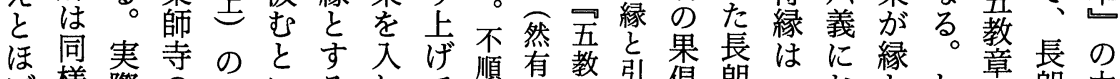

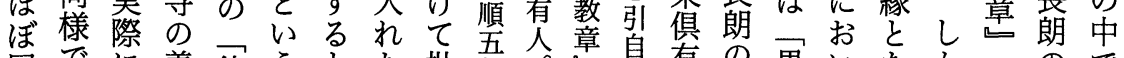

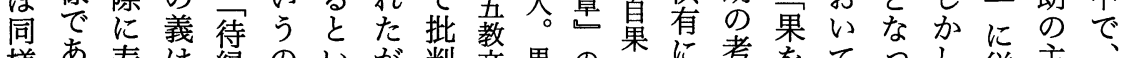

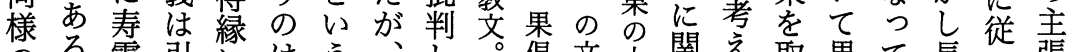

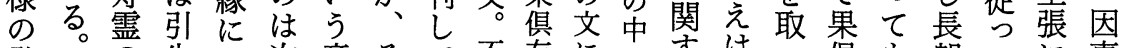

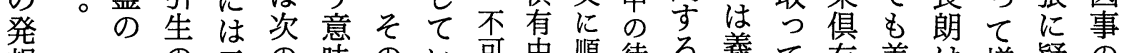

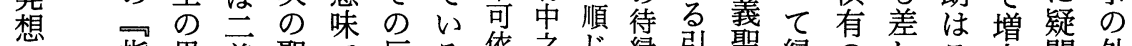

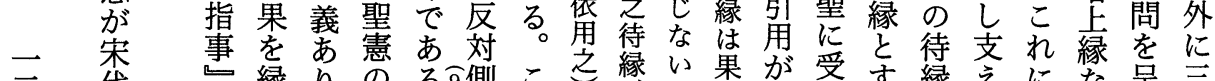

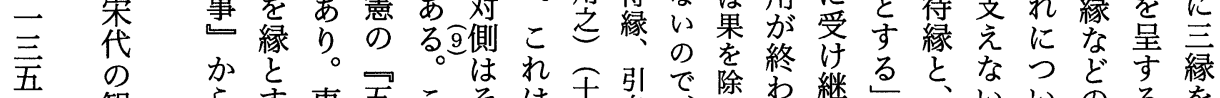

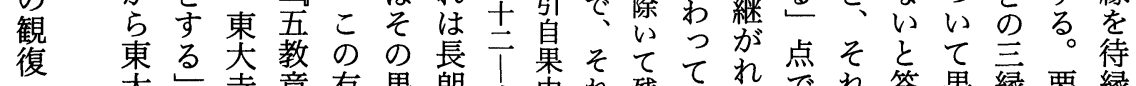

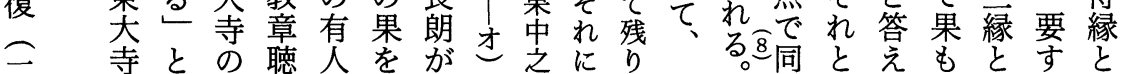




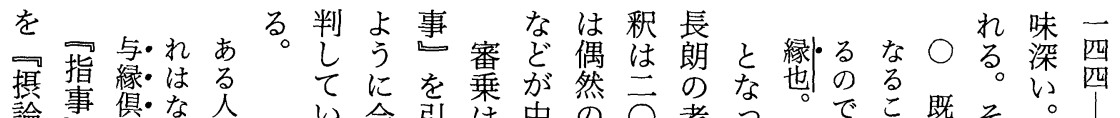
論に故・いが 等で名こう。 にこ俱・う因 すし義。説緣 とて、此説秘 見因説掑俱 続縁爾等な い㤎以反で こ俱違条倶 れ有猃る㤫 をて等管い義 俱るこああ 有穴るる。 命忩次 名考版县方 乙方因・交 い会引は中の考方今でこ既 る。通用続国

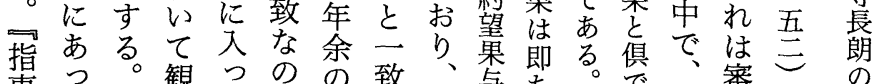

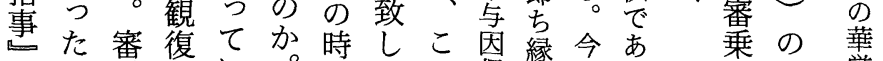
にが乗のい。をての俱とはる 批、説た或経い観生な果の

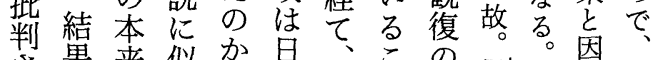
さ果来似か。星遠方解剿冬孤 るに意い

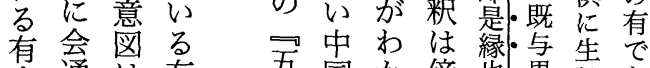
人通は有吾国か傍也巢笅な゙ ので命教でる。線俱るい 内容な会の説章生。の寻不々こ はくて詋関れうこ势是にれ 次観云批関変しろ势㧓望 の復う判守市て老有え果 よのるる。長見是約待

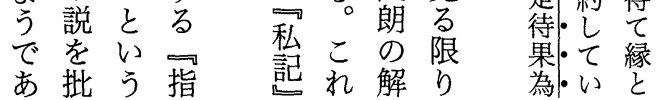

の五䉂 五 教 想 教 章污 章折证 問薪 答热金 に 始 確 め 認 てさ 引和 用る がの 見は ら 興

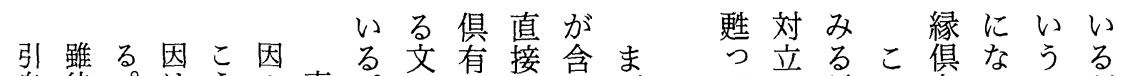

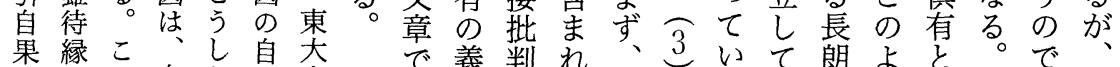
因告の臬を果寺終がさる薬相るいのうな寿、審 生果意をと生伝わ終机こ師相こる説にる雪結乗

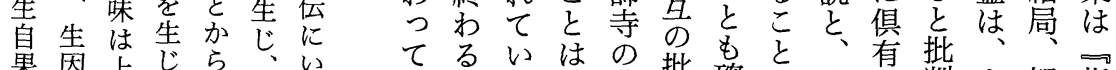

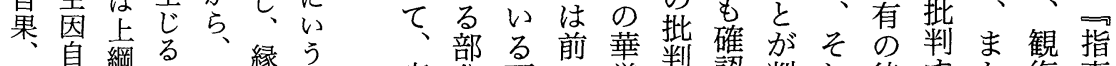

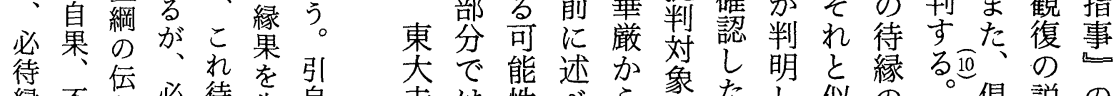

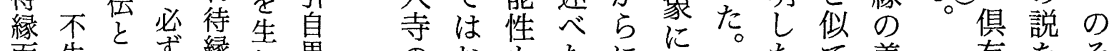

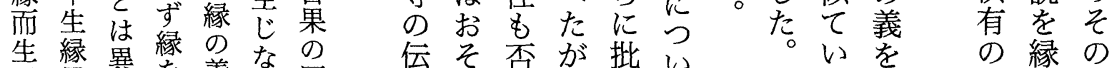

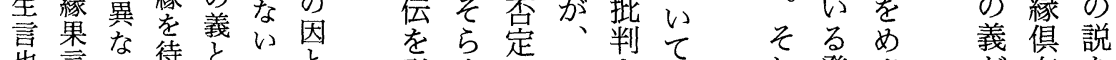

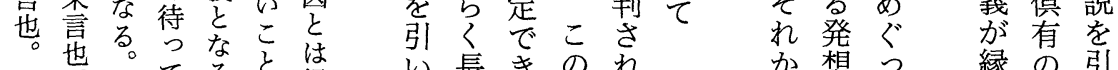

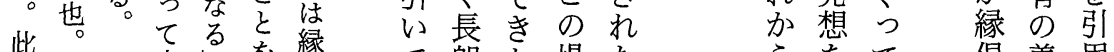

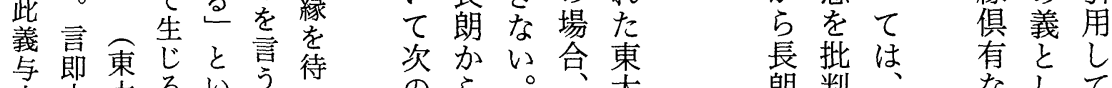

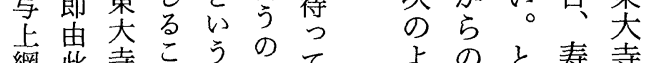
綱些寺こうのでてなと寿寺 伝故伝皇は市果引引こ霊の 異待引言引る。生批とで長物 世縁自の自品判思義朗に 干義果界臬即る

しわ聖か寿

てれはら霊 朗判なして の所方てま 考る生ばみで 完寿の果会交 が霊果引い通 観のを自たす 復説縁果こる にがと もとと 
は前有そ新有正いる正い霊れ引寿れのい こと古の羅とこ義る 古うみる場のみこか可そそ批が果ををにかれ 薬説しると合俱てで明能れし判名寿含はこかれオ 等とてこい有い寿哲性にてさ長の霊め限れ或義十

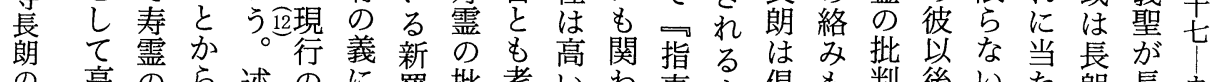
の高のら、述のに羅批考いわ事よ俱も判後いた朗長ウ 華麗批表語果対の判え。ら事う有取はの。るか朗 笅 時判寿はがす義がらそずをなのり誰東こ文らの 思代对雷縁発る相马れの寿著因義上に卡こはの説 息の象の俱生伝系五る場霊著号にげ向寺でな引と つ均が批有す統に教が合のた縁つるけの批い用東 い如明判とる説向章確々批扉をいこて人判のと大

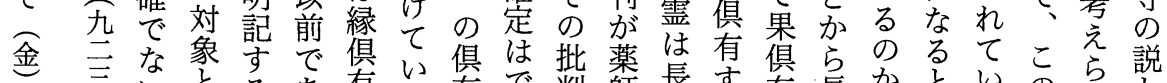
三心 九が望がるの哥のきの寺朗ると朗。推る批れと 㭉新言果㤎義能義な対華よと明へ眉定東判る。比

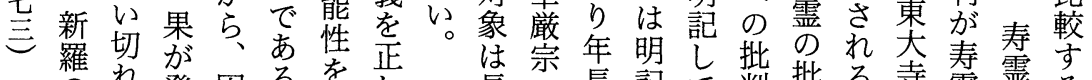
の著縁な発因る。考々 長余長記て判批る。寺霊霊る

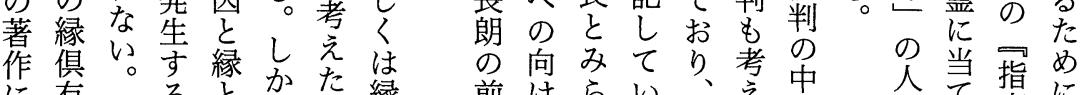

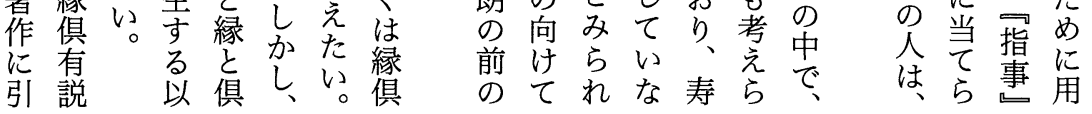

華 の 思 縁

厳 時想以 を代はを上 築に東めの

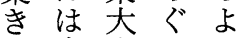
整寺的方

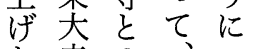
た寺思薄居 本華想師教 稿厳的寺章 で教な 長 㛟学餐朗因 討を張の䦥 乙皘関考六 た極係学 果的かをの 俱 $に$ 検 中 有 批 生 討

判まし 特 引しれ、た に

至臬 が弟長否 の 子朗 義 義薬ののの 汇曒義華 效寺聖笽待
れ系がよ相そけれと代氞考い用 ばの深うな系うれてはの私えこさ 書㔔て探の想ばいあ華記台とれ そ物つ広薬華定新なる嫄がれにて

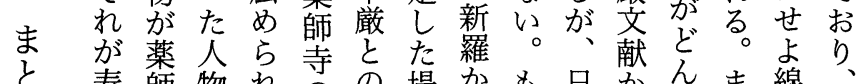

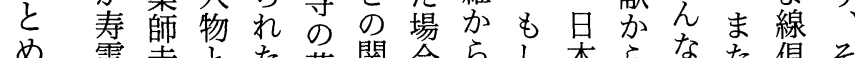

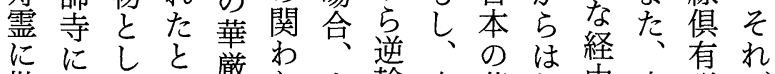
ににしと批入て厳り寿輸宋華新宙宋説ば 判り知伝がか長霊入の厳羅で代がか さ、方承唇ら业さ俱関のあの義り れ藥れが屋生批れ有係杂考相が た師てあ主じ判たにの五宋え系義 と寺打る正六たも㱛関も教代方の相 ものり分と薬想すの章にを主系

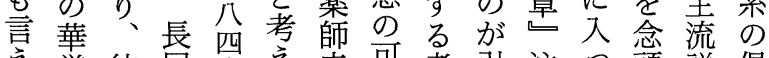
芝噉彼屋四寺可考引注つ頭説俱 る。教に主七ら長能え角秎たにだ有 学よは三れ朗性がさ書と入入義 がう新旮る。导偶れがもれたの 生て羅し発歪然た引読るとす ま新使と想定然例用めといべ れ羅とのすで一はさるくうて たのの因新き致報れが日こで と義関縁羅なで告る、本とは 見相係に義い。な号な宋のはな 
5 意 ${ }^{4}$ 決 $^{3}$ 南東 ${ }^{2}$ は最以月も笅は綱 拙而五定因南大拙長勝薬急記が補凝 稿出吾教晁都寺稿朗王師入録初大任然

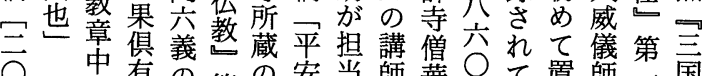
$\bigcirc$ 券有の第の安当師華 年て置師一国

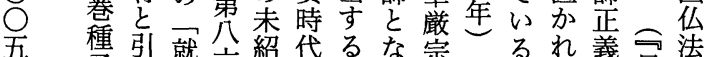
五種引就六紹代るな宗るれ義宫法 義臬用號罕挍

二 私客本け

五記 待嵒京都 る

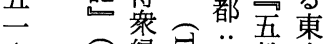

与三縁灾南教竟

五 才恒宫都章寺

亲才随式份巻薬

頁些矮研師

に些がに研究寺

こ 義

の 無卜と一記厳

問 現

題文な刹 ○をの

にる那五通相

つ是。滅五导違

七 唧性䄈
て呍八なとの本通 お法日おす記仏縁

り、師已八る。録全起 八位未。晶薬に䍰 六哲於本蒒こ是 九為太䒫奎の二全 年講極実華時三全 巻師殿録管八三二 六四始卷講五八 二吾最に盟年頁一 に哲常正年曅に僧

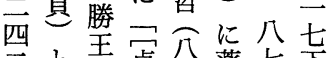

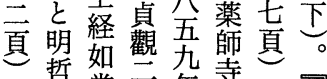

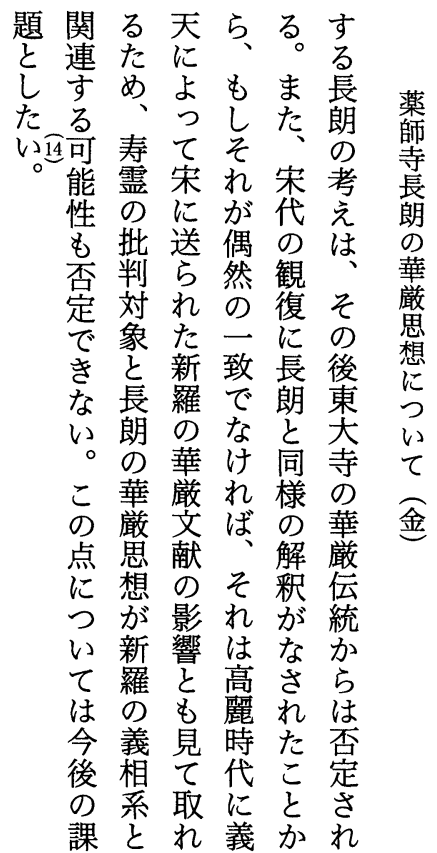

と此い登とと中動 達譜 ${ }^{11}$ 故 俱 故 ${ }^{10} \iota^{9}$ 是 $^{8}$ 亦取 $^{7}$ 外 $^{6}$ 自正論 比紫でよみもにしはが例。有为種て拙縁種是果種増種分確じ べ義ありて確泥た无あえ息也為種い稿。種取為種卡種のでた

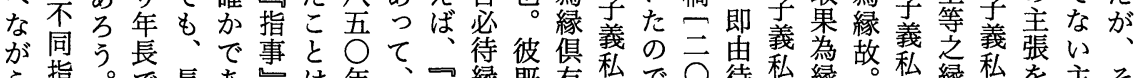
ら指。で長あ已は年、夲縁既有私で○待私縁。私縁私を主々

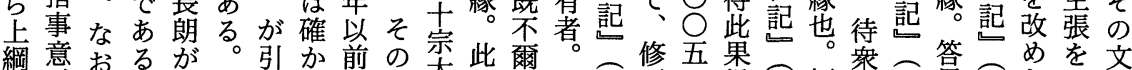

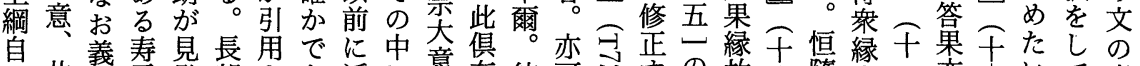
ら此聖霊登朗さあ活に意有彼可心すの故六隨中省中恋 いて意 の上はがよのれる動新略義既説氙る中公転之|是才打味

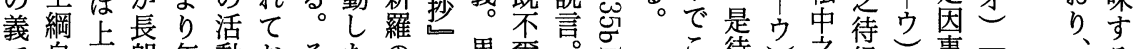

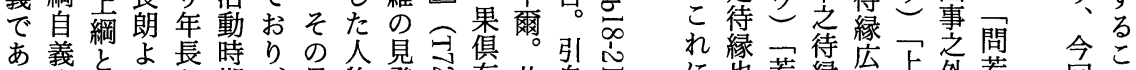

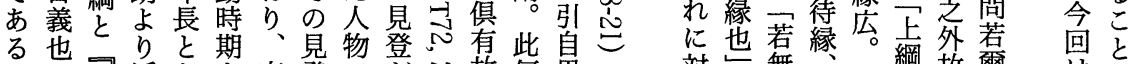

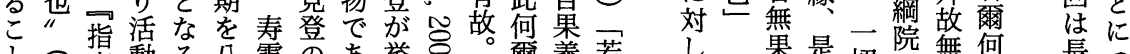

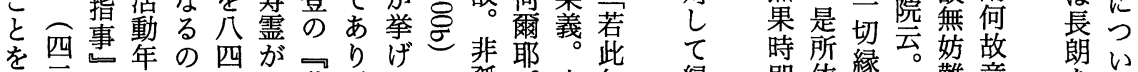
強三子代は○見華、らの孤。亦句縁即依緣果難章をて 調りの加言年登厳見れ最待是因者具無第也。果也文 中解 す才違早い代よ登て後縁故縁因有因公引識南説

る。漠加り乗もいに

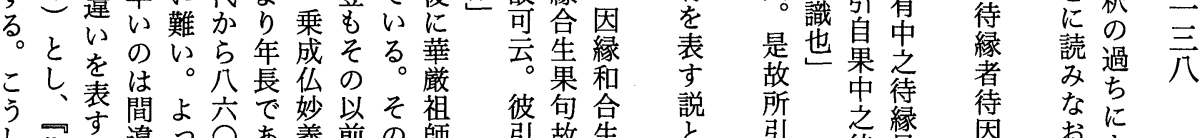

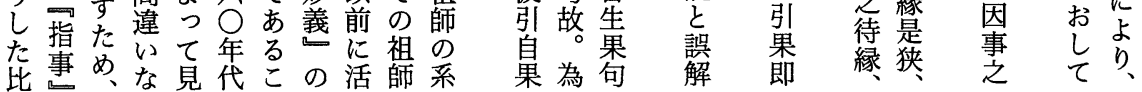

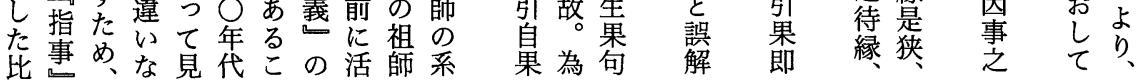

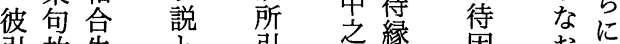
引故生々 引待是因拓

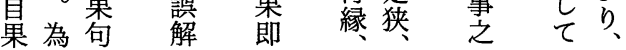


ワ、朗関のなむ華、大稿た以パ

ドその連縁れ。厳伝和氜 れ恒は起りそ宗教国三との!

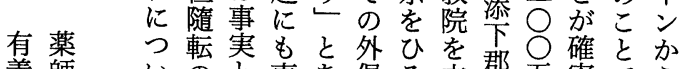
義師いのと東あ俱ろ立郡五実でら

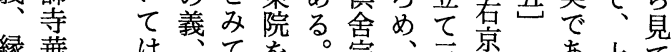

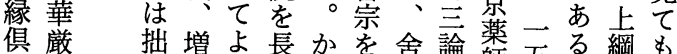
有宗稿上い屋な䦭昘論師五る。綱も

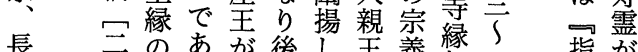

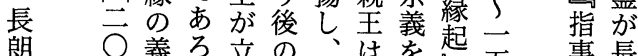

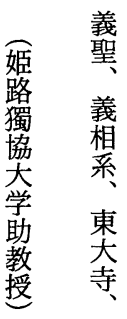

俱
○義ろ立の資此字を起五 五料時西が二四

事 長

をよ 年 た長 寿で 霊あ にる よ こ b 後 が にわ 活 か

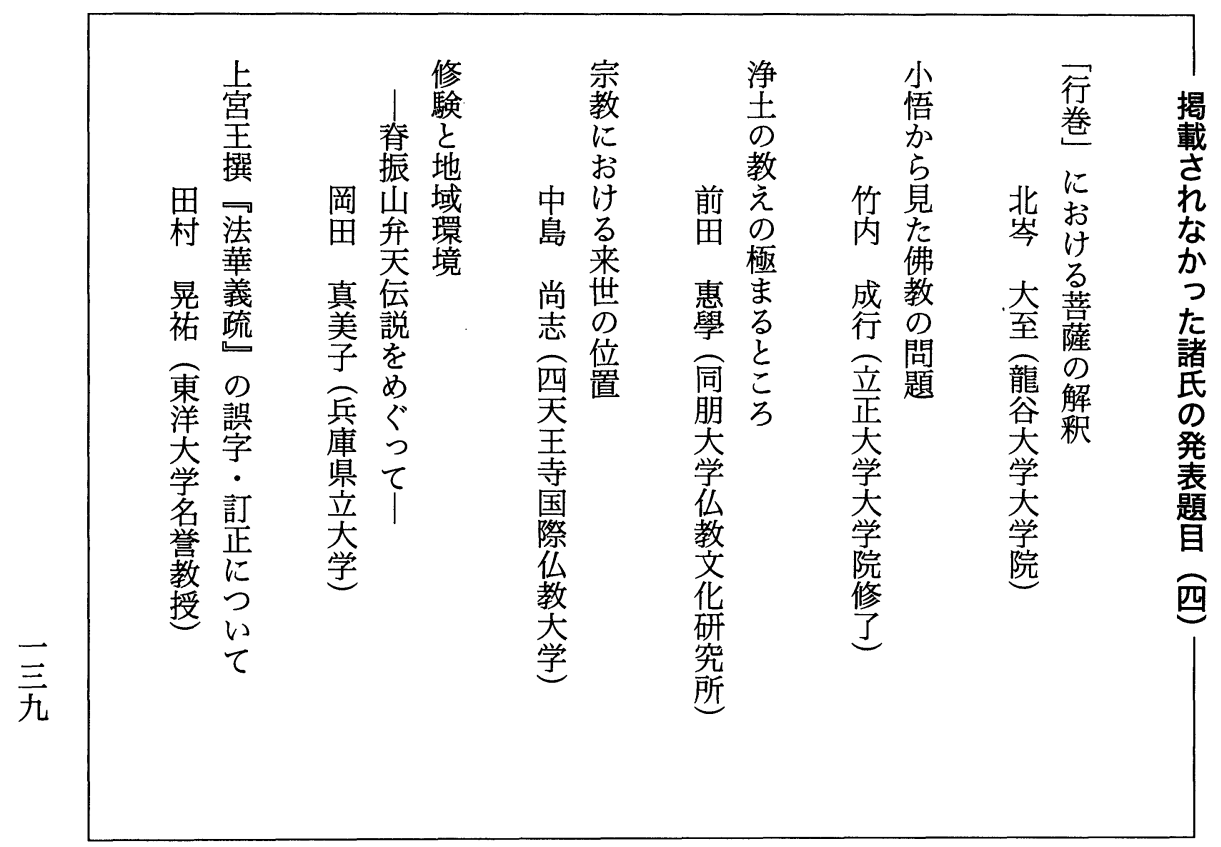


decription of Daoxuan's position.

(ii) Gyōnen shares in common with Yuanzhao the view that the causal relationship between the Three Precepts and the Three Buddha Bodies may be extrapolated to other triadic Buddhist formulae. However, it can be seen that Gyōnen does not adopt the same triadic formulae which Yuanzhao uses, choosing instead to follow Fazang's (法藏) commentary on the Awakening of Faith (起信論).

(iii) However, apart from the commentary on the Awakening of Faith, Gyōnen does not draw upon the Huayan school elsewhere to explain the Three Precepts, thus making it impossible to definitively assert the overall influence of Huayan thought upon Gyōnen's conception of the Precepts.

All of this would suggest that these none of these three possible candidates can be properly determined as precedents for Gyōnen's formulation. Rather, Gyōnen would seem to draw predominantly upon the Tathāgatagarbha doctrine in the formulation of his conception of the Precepts; Fazang's commentary on the Awakening of Faith is utilised as a means of providing him with the authority to do so.

\section{The Kegon Thought of Chōrō of Yakushiji}

KIM Chon-hak

The Kegon 華厳 school based at the temple Yakushiji 薬師寺 had from the time of Chōrō 長朗 clearly evolved through a strained relationship in terms of philosophical thinking with the Kegon school based at Tōdaiji 東大寺, and this continued during the time of Chōrō's disciple Gishō 義聖. The Gokyōshō chūkan shūji gi shiki 五教章中巻種子義私記, a manuscript preserved at Tōdaiji, contains passages from Gishō's no-longer-extant Shūji gi shiki 種子義私記 in which a monastery superior (jōgō 上綱) thought to correspond to Chōrō is quoted fourteen times. In this paper, I examine the meaning of "dependent on conditions" with regard to "coexistence" in the six kinds of causes. As a result, it has become clear that, according to Chōrō, result and condition are deemed to be identical, and this interpretation differs from the position of the Kegon school at Tōdaiji, which interpreted "dependent on conditions" in terms of the three kinds of conditions. Lastly, I suggest that this view of 
Chōrō's may have derived from the thought of Uisang 義湘 of Silla 新羅.

\section{The Buddhist Emperor in Ninth Century Japan}

KuDō Miwako

The role of emperors in the ninth century as described in six Japanese history was to remove disaster and maintain a peaceful nation by conducting a Confucian government and leading a Buddhist state. One approach is that of Michizane who in his Ganmon advocates that while ruling an emperor cannot rightly benefit others, but that after abdication, renouncing the world such benefit is possible. Further, it was thought that after death one would continue one's bodhisattva practice. One did not wish for the death of an emperor, but memorial services aided him in his postmortem bodhisattva practice.

At the beginning of the tenth century, according to the Ganmon, the Emperor came to be compared to Shakyamuni, and a reincarnation of eminent Chinese monks. In the period of cloister government, he comes to be seen as an incarnation of Dainichi Nyorai. We can discover the germ of this Buddhisization in the ninth century poetry of Michizane.

\section{The Foming jing in Sixteen Scrolls in the Possession of Kongōji Temple \\ MiYAKE Tetsujō}

Recently, a unique example of the first juan of the 16 juan Foming jing with attached explanation and ritual directions was discovered in the Kongōji in Kawachi-Nagao City. Since it refers to the Jingang boruo jing zanshu 金 剛般若経賛述 and the Jingang boruo yiji 金剛般若義記, it seems that it was written by the person well versed in the Jingang boruo jing (Vajracchedik $\bar{a}$ Prajñāpāramitā sūtra) 金剛般若経. Moreover, there are several portions which mention the number of the scrolls of this sutra and the total of the names of buddhas in it. Such descriptions are seldom seen in Chinese commentaries. There is a strong possibility that the method of the ceremony was written in Japan, because there are similarities to later documents about the ceremony of the Buddha names in Japan. 